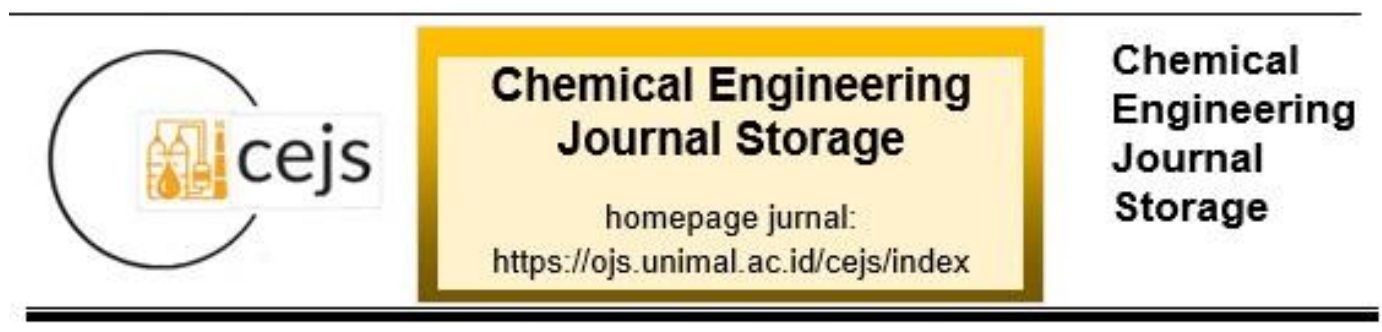

\title{
EKSTRAKSI GALAKTOMANAN DARI AMPAS KELAPA
}

\author{
Annisa, Azhari*, Suryati Suryati , Ishak Ishak, Nasrul ZA \\ Jurusan Teknik Kimia, Fakultas Teknik, Universitas Malikussaleh \\ Kampus Utama Cot Teungku Nie Reuleut, Muara Batu, Aceh Utara - 24355 \\ Korespondensi: 085362159499, e-mail: azhari@unimal.ac.id
}

\begin{abstract}
Abstrak
Tujuan penelitian ini adalah mengkaji kadar rendemen galaktomanan dari ampas kelapa dan mengkaji kondisi proses terbaik ekstraksi ampas kelapa. Metode yang digunakan adalah ekstraksi dengan pelarut aquades, dengan variasi perbandingan ampas kelapa terhadap pelarut dan suhu ekstraksi. Dari hasil penelitian diperoleh nilai tertinggi rendemen galaktomanan pada masing-masing kondisi rasio bahan baku (1:3) $\mathrm{gr} / \mathrm{ml}$ dan suhu $55^{\circ} \mathrm{C}$ dengan rendemen 8,489\%. Pada rasio bahan baku (1:4) gr/ml dan suhu $55^{\circ} \mathrm{C}$ dengan rendemen 8,736\%. Pada rasio 1:5 gr/ml dan suhu $55^{\circ} \mathrm{C}$ dengan rendemen $8,641 \%$. Nilai kadar air yang didapat pada hasil penelitian ini menunjukkan bahwa semakin tinggi suhu yang digunakan maka nilai kadar airnya semakin menurun. Dapat disimpulkan bahwa temperatur reaksi pada saat ekstraksi sangat mempengaruhi terhadap perolehan konsentrasi antioksidan yang didapat. Hasil uji kelarutan dalam air yang didapat adalah tidak larut dalam air (non polar), menunjukkan bahwa galaktomanan memang tidak larut dalam air.
\end{abstract}

Kata kunci: Ekstraksi, pelarut, ampas kelapa, galaktomanan

\section{Pendahuluan}

Kelapa merupakan salah satu tanaman yang sangat luas penggunaannya, selain untuk memenuhi kebutuhan pangan masyarakat, seperti santan, minyak goreng, gula dan air kelapa segar, kelapa juga dapat digunakan sebagai bahan baku industri. Salah satu contohnya adalah minyak kelapa yang digunakan sebagai bahan industri sabun, obat-obatan, mentega dan lain sebagainya. Hampir semua bagian dari tanaman kelapa dapat dimanfaatkan. Saat ini banyak sekali industri-industri pengolahan minyak kelapa seperti VCO (Virgin Coconut Oil) yang terbuat dari daging kelapa segar yang diolah pada suhu rendah atau tanpa pemanasan. Kegiatan industri ini menghasilkan limbah padat, salah satunya adalah ampas kelapa. Ampas kelapa dapat dimanfaatkan sebagai pakan ternak. 
Selain dapat digunakan sebagai pakan ternak ampas kelapa juga dapat digunakan sebagai bahan baku untuk memproduksi galaktomannan (Sari et al., 2019).

Galaktomanan adalah heteropolosakarida yang tersusun atas rantai manosa dan galaktosa yang mengandung unit mannopironisa dengan ikatan beta-(1-4) dan unit galaktopiranosa dengan ikatan alfa -(1-6). Galaktomanan adalah material serbaguna yang digunakan untuk banyak aplikasi, terutama sebagai pengental dan stabilizer pada emulsi. Galaktomanan banyak dimanfaatkan dalam berbagai sektor industri seperti industri tekstil, farmasi, biomedia, kosmetik dan makanan. Galaktomanan juga sering digunakan sebagai suplemen serat pangan dan menjadi bahan baku edible film. Galaktomanan adalah salah satu bagian dari bagian dari polisakarida, yang secara khusus dihasilkan dari tanaman leguminaceae .

Galaktomanan telah banyak digunakan sebagai pengental, stabilizer, emulsi, dan zat aditif pada berbagai industri makanan dan obat-obatan (Karina et al., 2019). Galaktomanan adalah heteropolisakarida yang terdiri dari rantai mannosa dan galaktosa. Galaktomanan adalah polisakarida heterogen yang terbentuk dari rantai utama $\beta$-(14)-D-manopiranosa dengan satu unit cabang $\alpha$-D-galaktopiranosa yang terikat pada posisi ó-(16), meskipun ada beberapa deviasi dari struktur dasar ini. Rasio manosa dan galaktosa $(\mathrm{M} / \mathrm{G})$ antara galaktomanan yang satu dengan yang lainnya berbeda menurut spesies (Barlina, 2015). Variasi distribusi galaktosa pada rantai utama menyebabkan variasi kelarutan, sifat alir dan sifat-sifat lainnya. Menyangkut sifat- sifat fisikokimia yang berbeda, galaktomanan adalah sejenis material yang serba guna yang digunakan untuk banyak aplikasi yaitu sebagai pengental dan stabilizer yang sangat baik dari emulsi, dan karena tidak bersifat toksik memungkinkan pemakaiannya sangat luas dalam industri- industri tekstil, farmasi, biomedis, kosmetik dan makanan. Sebagian besar galaktomanan yang digunakan dalam teknologi farmasi dan kosmetik biasanya merupakan gum yang tidak dimurnikan (Putri, 2014). Tujuan penelitian mengkaji kadar rendemen galaktomanan dari ampas kelapa dan mengkaji kondisi terbaik proses ekstraksi ampas kelapa. 


\section{Bahan dan Metode}

Bahan baku pada penelitian adalah ampas kepala yang sudah dikeringkan dan sudah dihaluskan hingga bisa melewati ayakan 50 mesh, metanol dan aquadest.

Penelitian ini terdiri dari tiga tahap yaitu proses preparasi sampel ampas kelapa, proses ekstraksi galaktomanan dari ampas kelapa dengan menggunakan pelarut aquades, dan proses pengendapan hasil ekstraksi menggunakan metanol. Pengujian pada penelitian ini dilakukan dengan uji rendemen, uji kadar air dan uji keasaman atau pH. Variasi percobaan dilakukan terhadap konsentrasi umpan campuran ampas kelapa dan air pada waktu 5 jam.

Preparasi sampel ampas kelapa dilakukan dengan memisahkan daging buah kelapa dari batok kelapa dengan cara diparut. Daging buah kelapa diperas dan diambil ampas kelapanya. Sampel ampas kelapa dicuci bersih dengan air yang mengalir hingga santannya sudah tidak ada. Pengeringan dilakukan dengan cara dioven selama 12 jam dengan suhu $50^{\circ} \mathrm{C}$ lalu dihaluskan dan dilakukan pengayakan dengan ukuran 50 mesh hingga ukurannya seragam.

Proses Ekstraksi dilakukan dengan menambahkan pelarut yaitu aquadest dengan ketentuan penelitian. Suhu pemanas sesuai veriabel yang ada $45^{\circ} \mathrm{C}, 50^{\circ} \mathrm{C}$, $55^{\circ} \mathrm{C}$ dan dijalankan dalam waktu 5 jam dengan kecepatan konstan.

Proses pengendapan hasil ekstraksi menggunakan methanol dilakukan dengan menyaring hasil ekstrasi dengan kertas saring. Kemudian ditimbang lalu ditambahkan agen pengendap dengan perbandingan 1:1, lalu ditunggu selama 8 jam. Endapan atas dipisahkan lalu di keringkan didalam oven dengan suhu rendah $30^{\circ} \mathrm{C}$ dengan waktu 15 menit. 


\section{Hasil dan Diskusi}

\subsection{Pengaruh perbandingan bahan baku/pelarut dan suhu terhadap nilai} rendemen

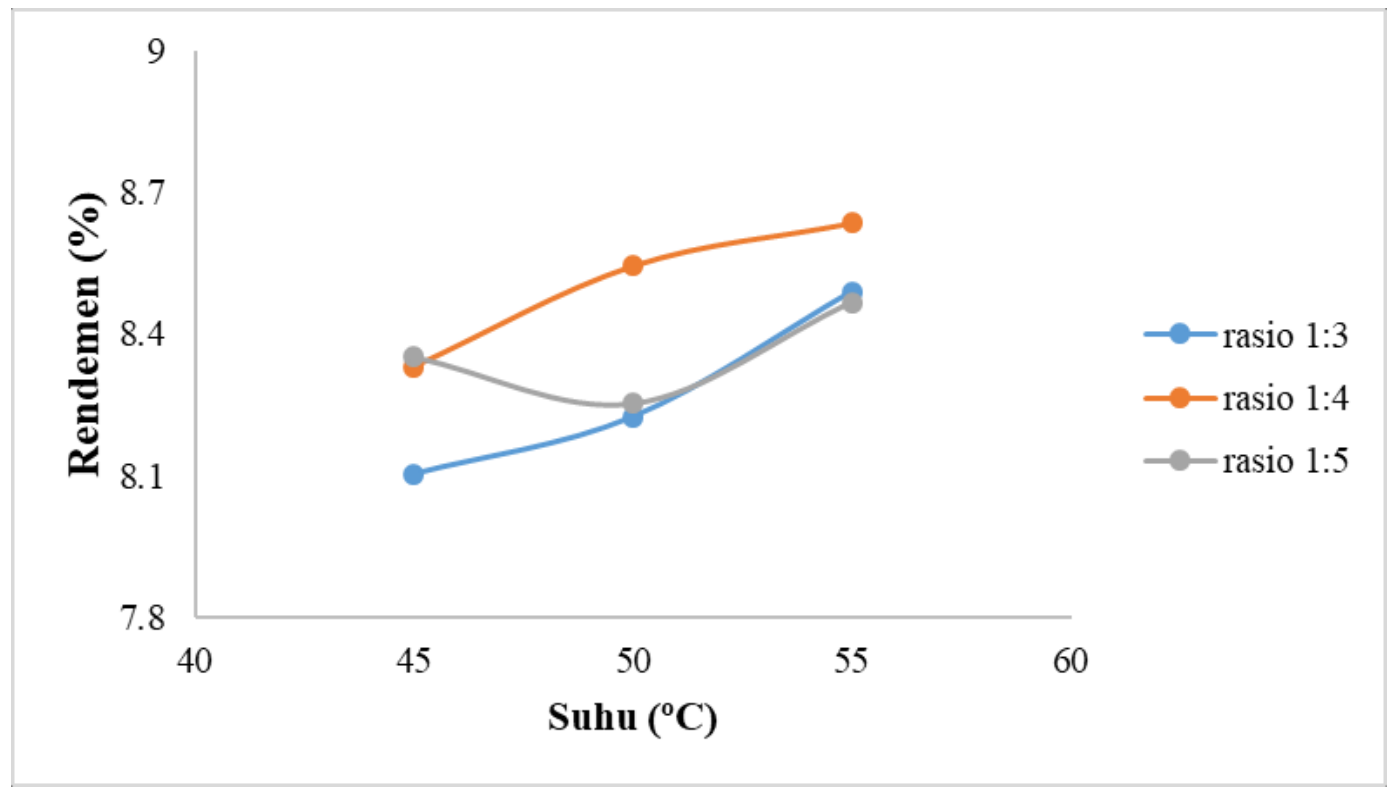

Gambar 1. Grafik pengaruh suhu terhadap nilai rendemen (\%)

Gambar 1 memperlihatkan bahwa pada rasio ampas kelapa dan pelarut (100:300) gr/ml menghasilkan rendemen yaitu pada suhu $45,50,55^{\circ} \mathrm{C}$ sebesar $8,103 \%, 8,224 \%, 8,489 \%$. Hasil tersebut menunjukkan bahwa rendemen tertinggi adalah $8,489 \%$ yaitu pada suhu $55^{\circ} \mathrm{C}$. Pada kondisi ini terlihat bahwa hasil yang didapat naik turun, disebabkan karena adanya pengaruh waktu dan temperatur pada saat proses ekstraksi sehingga mempengaruhi nilai rendemen yang dihasilkan.

Pada rasio ampas kelapa dan pelarut (100:400)gr/ml rendemen yang didapat yaitu sebesar 8,131\%, 8,545\%, 8,736\%, masing-masing dengan suhu 45, $50,55^{\circ} \mathrm{C}$. Hasil rendemen tertinggi didapat pada suhu $55^{\circ} \mathrm{C}$ yaitu sebesar $8,736 \%$. Sedangkan pada rasio (100:500) gr/ml rendemen terbanyak didapat sebesar $8,641 \%$ yaitu pada suhu $55^{\circ} \mathrm{C}$. Penelitian ini menunjukkan hasil rendemen terbanyak diperoleh pada rasio (100:400) $\mathrm{gr} / \mathrm{ml}$ dengan temperatur $55^{\circ} \mathrm{C}$ dan waktu ekstraksi 180 menit. 


\subsection{Pengaruh perbandingan bahan baku/pelarut dan suhu ekstraksi terhadap nilai kadar air}

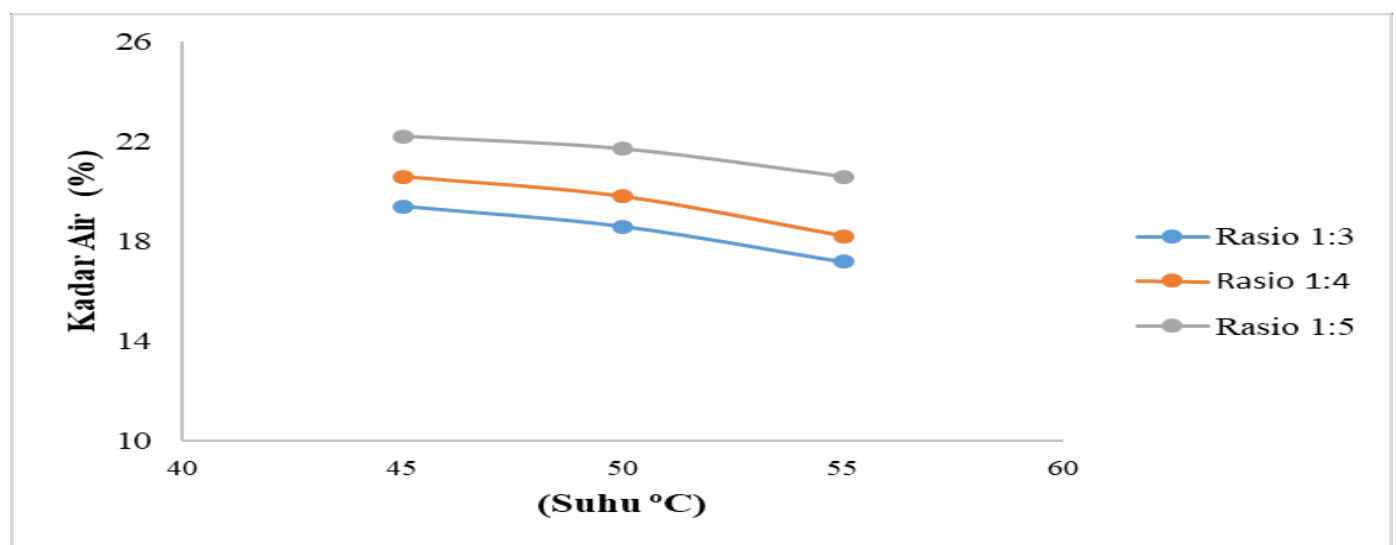

Gambar 2 Grafik hubungan suhu terhadap kadar air (\%)

Dari Gambar 2 dapat dilihat bahwa kadar air dari setiap rasio perbandingan bahan baku dengan pelarut menurun seiring naiknya temperatur ekstraksi. Hal ini dinyatakan semakin berkurangnya nilai kadar air maka sangat menentukan hasil yang didapatkan semakin tinggi. Dari grafik, nilai kadar air tertinggi masingmasing rasio adalah pada suhu $45^{\circ} \mathrm{C}$. Semakin naik suhu maka nilai kadar air yang dihasilkan semakin menurun disebabkan kandungan air dalam bahan semakin berkurang. Hasil kadar air terendah dari masing-masing rasio adalah sebesar 17,2 $\%$ untuk rasio (100:300) gr/ml, 16,3\% untuk rasio (100:400) gr/ml dan 18,8 \% untuk rasio (100:500) gr/ml.

\subsection{Pengaruh perbandingan bahan baku/pelarut dan suhu ekstraksi terhadap derajat keasaman (pH)}

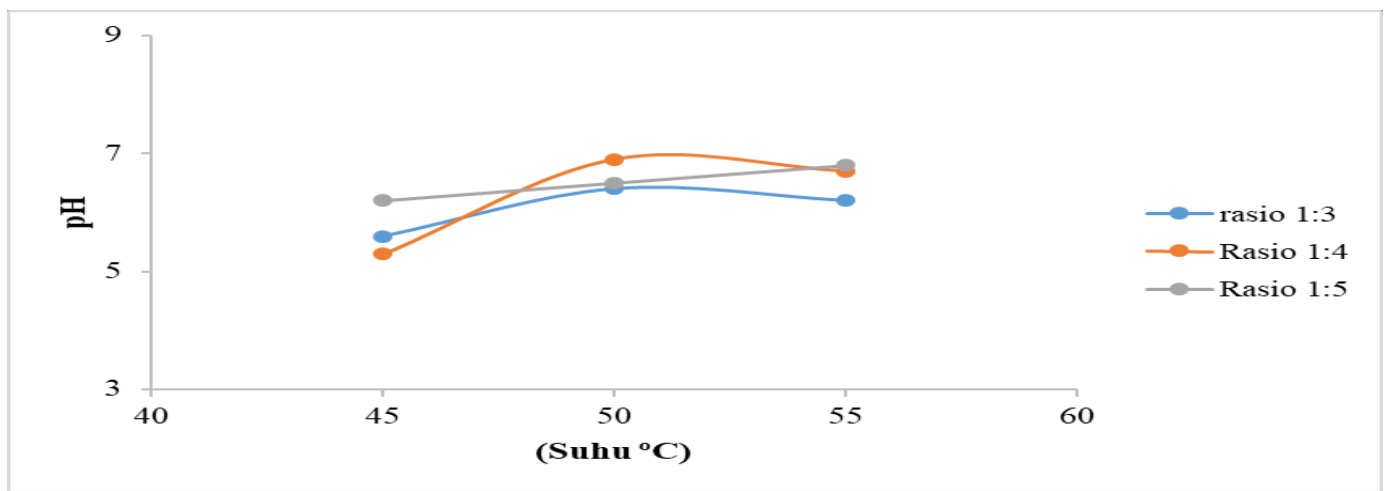

Gambar 3 Pengaruh Perbandingan Bahan Baku dan Suhu Terhadap (pH). 
Berdasarkan hasil pengamatan terhadap ekstraksi galaktomanan ampas kelapa, diketahui bahwa pH galaktomanan ampas kelapa pada rasio 1:3 dengan suhu $45^{\circ} \mathrm{C}$ adalah 5,6 sednagkan pada suhu $50^{\circ} \mathrm{C}$ adalah 6,4 dan pada suhu $55^{\circ} \mathrm{C}$ adalah 6.2. Rasio $1: 4$ dengan suhu $45^{\circ} \mathrm{C}$ adalah 5,3 sedangkan pada suhu $50^{\circ} \mathrm{C}$ adalah 6,9 dan pada suhu $55^{\circ} \mathrm{C}$ adalah 6.7. Adapun pada Rasio 1:5 dengan suhu $45^{\circ} \mathrm{C}$ adalah 6,2 sednagkan pada suhu $50^{\circ} \mathrm{C}$ adalah 6,5 dan pada suhu $55^{\circ} \mathrm{C}$ adalah 6.8. Berdasarkan grafik 4.3, $\mathrm{pH}$ tertinggi adalah 6,9 yang berada pada suhu ekstraksi $50^{\circ} \mathrm{C}$ dengan waktu 3 jam dan rasio 1:4. Sedangkan $\mathrm{pH}$ terendah adalah 5,3 yang berada pada suhu ekstraksi $45^{\circ} \mathrm{C}$ dengan waktu 3 jam dan rasio 1:3. Hasil penelitian berdasarkan Tabel 4.3 rata-rata $\mathrm{pH}$ yang dihasilkan berkisar 5-6, yang menghasilkan warna merah. Adapun grafik hubungan antara suhu ekstraksi terhadap derajat keasaman $(\mathrm{pH})$ yang tertinggi adalah 6,9 pada suhu $50^{\circ} \mathrm{C}$ dan waktu 3 jam dan sedangkan $\mathrm{pH}$ terendah adalah 5,1 pada suhu $40^{\circ} \mathrm{C}$ waktu 3 jam. Adapun standar nasional untuk $\mathrm{pH}$ sabun mandi cair adalah 5-7, hal ini menunjukkan bahwa ekstraksi galaktomanan ampas kelapa pada penelitian yang dilakukan sudah sesuai dengan SNI ekstraksi galaktomanan ampas kelapa.

\section{Simpulan dan Saran}

Hasil analisa uji rendemen, derajat keasaman $\mathrm{pH}$, kadar air (\%), dan uji kelarutan dalam air sudah sesuai dengan standar (SNI-06-4085-1996) dengan ekstraksi galaktomanan ampas kelapa. Nilai kadar air yang didapat pada hasil penelitian ini menunjukkan bahwa semakin tinggi suhu yang digunakan maka nilai kadar airnya semakin menurun. Berdasarkan hasil evaluasi, rasio 1:4 dengan suhu $55^{\circ} \mathrm{C}$ pada ekstraksi galaktomanan ampas memberikan karakteristik galaktomanan yang terbaik. Penelitian ini dapat dilanjutkan dengan mengamati tentang pelarut lain agar lebih meningkatkan hasil dan sebaiknya digunakan pelarut edible supaya produk galaktomanan dapat digunakan untuk makanan dan kosmetik. 


\section{Daftar Pustaka}

Aulia, I., Subagio, A., \& Prasetyo, A. (2014). Pengaruh Pemberian Galaktomanan dari Daging Kelapa Lokal (Cocos nufitera L) terhadap Kadar Glucagon Like Peptide-1 (GLP-1) pada Tikus Wistar Jantan yang Hiperkolesterolemia. Pustaka Kesehatan, 2(2), 239-242.

Azis, R., \& Akolo, I. R. A. R. (2018). Karakteristik tepung ampas kelapa. Journal Of Agritech Science (JASc), 2(2), 104.

Barlina, Rindengan. (2015). Extraction of galactomannan on the coconut meat, "sapal", and function for food. Perspektif, 14(1), 37-49.

Barlina, Rindengan. (2015). Ekstrak Galaktomanan Pada Daging Buah Kelapa Dan Ampasnya Serta Manfaatnya Untuk Pangan. Jurnal Perspektif, 14(1),

Karina, A. E., Pujaningsih, R. I., \& Yudiarti, T. (2019). Total Bakteri dan Fungi serta Kandungan Nutrisi dari Ampas Kelapa yang Diberi Ekstrak Daun Kersen dengan Lama Penyimpanan Berbeda. Jurnal Sain Peternakan Indonesia, 14(4), 359-367.

Maulyta, A. S. (2013). Pengaruh Pemberian Ekstrak Galaktomanan Dari Daging Buah Kelapa (Cocos Nucifera L.) Terhadap Peningkatan Kadar Scfa (Short Chain Fatty Acid) Pada Feces Tikus Wistar Jantan Hiperkolesterolemia.

Prasetyo, A., \& Winarti, S. (2019). Karakteristik effervescent prebiotik galaktomanan dari ampas kelapa. Jurnal Teknologi Pangan, 13(2).

Purawisastra, S., \& Sahara, E. (2010). Isolasi galaktomanan ampas kelapa rumah tangga dan bungkil industri minyak kelapa.

Putri, M. F. (2014). Kandungan gizi dan sifat fisik tepung ampas kelapa sebagai bahan pangan sumber serat. TEKNOBUGA: Jurnal Teknologi Busana Dan Boga, 1(1).

Sari, N., Mairisya, M., \& Kurniasari, R. (2019). Ekstraksi Galaktomanan Dari Ampas Kelapa Sebagai Bahan Baku Bioplastik. Prosiding SNST Fakultas Teknik, 1(1).

Sari, N., Mairisya, M., Kurniasari, R., \& Purnavita, S. (2019). Bioplastik Berbasis Galaktomanan Hasil Ekstraski Ampas Kelapa Dengan Campuran Polyvinyl Alkohol. METANA, 15(2), 71-78. 